\title{
Stem cell therapy in ischemic stroke
}

\section{Role of IV and intra-arterial therapy}

Vivek Misra, MD

Michael M. Ritchie, MS

Laura L. Stone, BA

Walter C. Low, PhD

Vallabh Janardhan, MD

Correspondence \& reprint requests to Dr. Janardhan: drvallabh@yahoo.com

\section{ABSTRACT}

Objective: Cell-based therapies are being investigated as an adjunct to IV thrombolysis or mechanical thrombectomy in ischemic stroke. This review summarizes the potential applications as well as challenges of intravascular cell delivery in ischemic stroke.

Method: We conducted a search of Medline as well as the clinicaltrials.gov Web site for all ongoing human clinical studies using stem cells in ischemic stroke patients.

Result: The pros and cons of the various donor cell types and routes of cell delivery, including intravascular delivery, in ischemic stroke are discussed. In addition, the potential challenges in translation from bench to bedside, the optimal techniques for intravascular cell delivery, and an updated comprehensive list of ongoing clinical trials in ischemic stroke are highlighted.

Conclusions: Stem cells have shown a promising role in ischemic stroke, in preclinical studies as well as initial pilot studies. Further studies are needed to assess intravascular cell therapy as a potential adjunct to thrombolysis or mechanical thrombectomy in ischemic stroke. Neurology ${ }^{\circledR} 2012 ; 79$ (Suppl 1):S207-S212

\section{GLOSSARY}

BMMNC = bone marrow mononuclear cell; IA = intra-arterial; IC = intracerebral; ICV = intracisternal/cerebroventricular.

Cell therapy is emerging as a promising new modality for enhancing neurologic recovery in ischemic stroke. ${ }^{1}$ Numerous basic science studies have demonstrated positive results in animal models of ischemic stroke following implantation of progenitor cells derived from various sources, including adipose, human fetal/embryonic tissue, bone marrow, peripheral, and umbilical cord blood (figure). ${ }^{2}$ These animal studies have utilized various methods of cell delivery or implantation (table 1), including direct intracerebral (IC) injection, intracisternal/cerebroventricular (ICV), or intravascular routes of delivery such as IV or intra-arterial (IA) infusion.

Methods of cellular delivery and implantation. Intracerebral. Direct injection is invasive, and despite being a precise method of cellular delivery and implantation, it results in a poor distribution of cells in the target lesion. ${ }^{3}$ Initial pilot human studies investigating stereotactic IC cell implantation in patients with chronic stroke also reported adverse events, including seizures, syncope, asymptomatic subdural hematoma, transient motor worsening, and enhancing lesions on MRI. 4,5

Intracisternal/cerebroventricular. The ICV route of cell delivery is less invasive than direct IC implantation but is also associated with variable cell migration to the ischemic site. ${ }^{6,7}$ In a pilot human study investigating ICV delivery in 10 chronic stroke patients (7 ischemic and 3 hemorrhagic), some patients developed fever and meningeal signs 48 hours after cellular delivery via ICV route. ${ }^{8}$

$I V$. Infusion is the least invasive method, allowing wide distribution of cells with exposure to chemotactic signals that potentially guide them toward the target ischemic lesion. This method, however, results in cells being trapped by peripheral organs, including the lungs, liver, and spleen, thereby limiting potential engraftment in the ischemic lesion in the brain. ${ }^{2}$ Since patients with ischemic stroke commonly have associated cardiac and renal impairment, there is also a potential for the cells reaching these organs, with further reduction in cell delivery to the ischemic brain. ${ }^{9,10}$ Given that IV cell delivery is least invasive, this method of

From the Texas Stroke Institute (V.M., V.J.), HCA North Texas Division, Dallas-Fort Worth; Department of Neurology (V.M.), University of Texas, Houston; and the Stem Cell Institute (M.M.R., W.C.L.), Graduate Program in Neuroscience (L.L.S., W.C.L.), and Department of Neurosurgery (W.C.L.), University of Minnesota (M.M.R., L.L.S., W.C.L.), Minneapolis.

Go to Neurology.org for full disclosures. Disclosures deemed relevant by the authors, if any, are provided at the end of this article. 


\section{Figure Phase contrast image of human umbilical cord blood stem cells}

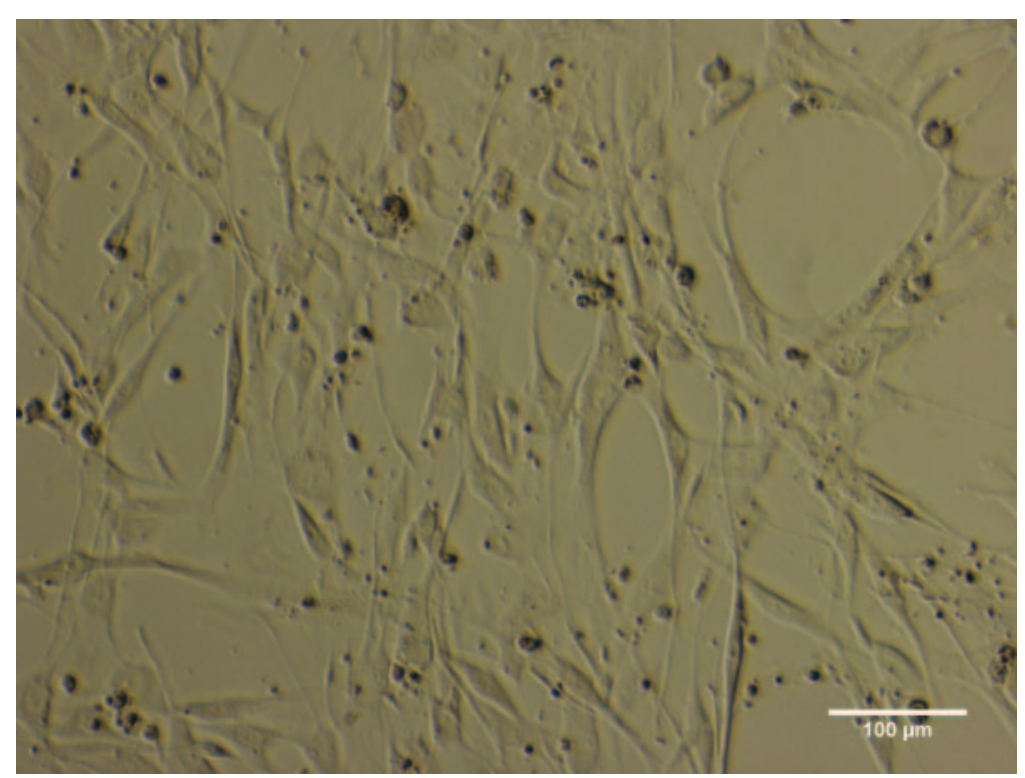

delivery has been investigated in patients with chronic stroke. In a placebo-controlled phase I/II trial of 30 patients with chronic stroke, 5 in the treated group received autologous mesenchymal stromal cells at 1 to 2 months from the onset of symptoms. This method was reportedly safe and feasible

Table 1 Routes of cell delivery

$\begin{array}{lll}\text { Route } & \text { Pros } & \text { Cons } \\ \text { IC } & \begin{array}{l}\text { Precise method of } \\ \text { implantation }\end{array} & \text { Invasive }\end{array}$

Nonuniform distribution in the ischemic lesion

Reported adverse events in pilot human studies

Potential for bleeding risks in stroke patients receiving antiplatelets or anticoagulants

ICV Less invasive
than IC

Variable cell migration in ischemic lesion

Immature neuronal and

\section{Reported adverse events in a} human study, including meningitis

Potential for bleeding risks in stroke patients receiving antiplatelets or anticoagulants

\section{Most feasible} route; least

Poor cell engraftment at the cerebral ischemic lesion due found safe in pilot peripheral filtering organs human studies (such as lung capillaries)

IA Less invasive than Potential for microvascular $\mathrm{IC}$ and ICV; high occlusions rates of cell engraftment with uniform distribution at the ischemic site hemopoietic

\section{Cell types used in}

pilot human studies

Human neuronal, fetal porcine

Autologous mesenchymal stromal; autologous bone marrow mononuclear

Autologous bone marrow mononuclear

Abbreviations: IA = intra-arterial; IC = intracerebral; ICV = intracisternal/cerebroventricular.

in the short term, ${ }^{11}$ as well as on long-term followup, with improved neurologic recovery in those patients receiving cellular therapy. ${ }^{12}$ Another unblinded single-arm study demonstrated safety and feasibility with IV infusion of autologous mesenchymal cells in 12 patients post-stroke onset (range, 36-133 days). ${ }^{13}$ Until recently, all human studies had reported results in chronic stroke patients. Recently, an open-label prospective human study demonstrated safety and feasibility with IV mononuclear cell infusion in 10 patients with acute stroke. ${ }^{14}$ Patients in this study underwent bone marrow harvest and subsequent IV cell infusion within 24 to 72 hours of stroke onset. This methodology is supported by a preclinical study in which rats with common carotid artery/middle cerebral artery occlusion performed better on neurologic tests with IV mononuclear cells infused up to 72 hours, compared with 1 week from stroke onset. ${ }^{15}$ However, similar to prior animal experiments, this study also found cells sequestered in the spleen, lung, liver, and kidney.

Intra-arterial. Cell delivery involves endovascular infusion of progenitor cells directly in the artery perfusing the ischemic tissue. This route of cell delivery also bypasses the peripheral filtering organs, thereby increasing cell delivery to the target ischemic tissue with uniform distribution. Animal studies have demonstrated higher rates of cell engraftment with IA delivery, ${ }^{16,17}$ as well as a higher concentration of cells in the target ischemic lesion with IA, ${ }^{16}$ compared with IV cell infusion. ${ }^{18,19}$ One preclinical study comparing IV and IA autologous bone marrow mononuclear cell (BMMNC) delivery found significant reduction in infarct volume, higher cell engraftment, and improved motor function with IA delivery. ${ }^{20}$ The authors attributed this "significant neuroprotective effect" in the IA group to the larger number of implanted cells in the brain during early reperfusion. Despite the advantage of increased cell homing in the ischemic lesion, few animal studies have also raised concern with the potential for microvascular occlusion, worsening ischemia, and higher mortality with IA delivery. ${ }^{19,21}$ A recent preclinical study investigated the etiology of cerebral blood flow reduction and microvascular occlusion following IA neural progenitor cell infusion. ${ }^{22}$ The investigators attributed the microstrokes to the prior procedural technique, but that can be overcome with preserved anterograde flow. ${ }^{22}$

Mechanisms of action of stem cells in ischemic stroke. Preclinical studies on the use of stem cells for the treatment of stroke have now clearly demonstrated that the administration of different types and sources of stem cells can ameliorate neurologic deficits, and in some cases significantly reduce the size of the infarct. For example, IV administration of human cord 


\section{Table 2 Donor cell types}

\section{Cell sources} and types

1. Bone marrow, autologous allogeneic

Readily available for infusions in acute situations

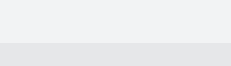 \\ 3. Umbilical cord, mononuclear}

\section{Could be readily available in the acute stroke setting}

\section{Bone marrow,}

\section{Cons \\ Need bone marrow harvest}

Need specialized labs for cell separation and processing

Not readily available for infusion in acute situations

Potential risk of rejection

Need bone marrow harvest

Need specialized labs for cell separation and harvesting

Requires large numbers of donors

Low passage number

Need specialized labs for cell separation and processing

Potential risk of rejection

4. Umbilical cord, stem

Could be readily available in Need specialized labs for cell separation the acute stroke setting

Capable of high passage and therefore requires few donors

5. Embryonic stem

Potential for neural replacement

Could be readily available in Potential teratoma formation the acute stroke setting

\begin{tabular}{|c|c|c|}
\hline & & $\begin{array}{l}\text { Need specialized labs for cell separation } \\
\text { and processing }\end{array}$ \\
\hline & & Potential risk of rejection \\
\hline \multirow{3}{*}{$\begin{array}{l}\text { 6. Induced pluripotent } \\
\text { stem, autologous }\end{array}$} & Lack of immune rejection & Potential teratoma formation \\
\hline & & $\begin{array}{l}\text { Need specialized labs for cell separation } \\
\text { and processing }\end{array}$ \\
\hline & & Not readily available in the acute setting \\
\hline \multirow[t]{3}{*}{$\begin{array}{l}\text { 7. Induced pluripotent } \\
\text { stem, allogeneic }\end{array}$} & $\begin{array}{l}\text { Could be readily available in } \\
\text { the acute stroke setting }\end{array}$ & Risk of rejection \\
\hline & & Potential teratoma formation \\
\hline & & $\begin{array}{l}\text { Need specialized labs for cell separation } \\
\text { and processing }\end{array}$ \\
\hline \multirow{2}{*}{$\begin{array}{l}\text { 8. Direct } \\
\text { reprogramming of } \\
\text { somatic cells, } \\
\text { autologous }\end{array}$} & Lack of immune rejection & $\begin{array}{l}\text { Need specialized labs for cell separation } \\
\text { and processing }\end{array}$ \\
\hline & & Not readily available in the acute setting \\
\hline $\begin{array}{l}\text { 9. Direct } \\
\text { reprogramming of } \\
\text { somatic cells, } \\
\text { allogeneic }\end{array}$ & $\begin{array}{l}\text { Could be readily available in } \\
\text { the acute stroke setting }\end{array}$ & Risk of rejection \\
\hline
\end{tabular}

Need specialized labs for cell separation and processing

blood stem cells into laboratory rodents 2 days after ischemic stroke has been shown to reduce infarct lesion volume by approximately $50 \%$ and improve neurologic function by approximately $55 \% .^{23}$

Early studies of stem cell therapy for treating stroke were based on the rationale of replacing neural cells that were lost as a result of ischemic brain injury. These cells could be neuronal, astrocytic, oligoden-

droglial, or endothelial in phenotype. However, it has now become clear that in spite of improvements in neurologic outcome and reductions in infarct size, the mechanism of cell replacement in stem cell therapy for stroke appears to play a more modest role than originally envisioned. Recent reports have shown that the administration of stem cells in animals with stroke can induce the reinstatement of functional connectivity, as determined by functional MRI. ${ }^{24}$ This, in turn, may be mediated by the outgrowth of nerve fibers of endogenous neurons. ${ }^{23,25}$ Other studies have demonstrated that stem cell therapy results in the upregulation of growth factors that may be responsible for the outgrowth of these endogenous fiber processes ${ }^{26}$ and for the inhibition of inflammatory processes, ${ }^{27}$ which may lead to secondary cell loss within the brain. These observations offer intriguing alternative mechanisms that may underlie the restorative effects noted with stem cell therapy following stroke and provide a rationale basis for clinical trials.

Challenges in translating intravascular cellular delivery from bench to the bedside. All routes of cell delivery have appeared promising in animal studies, although the intravascular routes of delivery such as IV and IA are less invasive than IC and ICV routes. Despite promising results in animal studies, several key questions remain to be answered before proceeding to human trials, such as choice of cells for delivery or implantation (table 2), the timing of cellular therapy, and the dose of cells delivered or implanted. Despite these knowledge gaps, initial clinical trials investigating cell therapy in chronic as well as subacute strokes have already begun worldwide (table 3).

Choice of cells. The authors describe the pros and cons of the various donor cell types and their relevance to acute ischemic stroke (table 2). The longer timeframe required for obtaining cells from autologous sources limits their potential application in patients with hyperacute strokes. Cells derived from umbilical $\operatorname{cord}^{23,28}$ or placenta ${ }^{29}$ could be potentially investigated in clinical studies in patients receiving IV or IA thrombolytic therapy in the initial few hours after a stroke.

Timing of cell therapy. Unlike IV or IA revascularization therapies, there are no clearly defined therapeutic time windows for cell therapy with all routes of delivery. Since most ongoing human studies use cells from autologous sources, these trials are investigating therapeutic windows ranging from a few days to several months.

Dose. Preclinical studies have demonstrated a dose-response relationship, with higher IV cell dose resulting in smaller infarct volumes. ${ }^{30-31}$ Given that IV infusion results in sequestration of cells in peripheral organs, it is theoretically conceivable that IA de- 


\begin{tabular}{|c|c|c|c|c|c|c|c|c|}
\hline I & IC & СТХОЕОЗ neural stem & $6 \mathrm{mo}-5 \mathrm{y}$ & Safety & Functional outcome & $\begin{array}{l}\text { Glasgow South } \\
\text { General Hospital }\end{array}$ & $\begin{array}{l}\text { United } \\
\text { Kingdom }\end{array}$ & NCT01151124 \\
\hline $\mathrm{I} / \mathrm{II}$ & IC & Modified stem, SB623 & $6-12 \mathrm{mo}$ & Safety & Functional outcome & $\begin{array}{l}\text { Stanford University, } \\
\text { University of } \\
\text { Pittsburgh }\end{array}$ & $\begin{array}{l}\text { United } \\
\text { States }\end{array}$ & NCT01287936 \\
\hline II & IC & $\begin{array}{l}\text { Autologous peripheral CD } \\
34+\text { stem }\end{array}$ & $\begin{array}{l}>6 \mathrm{mo} \\
<60 \mathrm{mo}\end{array}$ & Functional outcome & $\begin{array}{l}\text { Functional outcome, } \\
\text { imaging }\end{array}$ & $\begin{array}{l}\text { China Medical } \\
\text { University Hospital }\end{array}$ & Taiwan & NCT00950521 \\
\hline I & IV, IT & Umbilical cord, mesenchymal & $\begin{array}{l}\text { IV, } 7-14 \mathrm{~d} \text {; IT, } \\
1 \text { wk after IV }\end{array}$ & Functional outcome & $\begin{array}{l}\text { Evoked potentials and } \\
\text { MRI changes }\end{array}$ & $\begin{array}{l}\text { General Hospital of } \\
\text { Chinese Armed Police } \\
\text { Forces }\end{array}$ & China & NCT01389453 \\
\hline $\mathrm{I} / \mathrm{Ila}$ & IV & $\begin{array}{l}\text { Autologous bone marrow } \\
\text { mononuclear }\end{array}$ & $24-72 \mathrm{~h}$ & Safety, feasibility & Functional outcome & $\begin{array}{l}\text { University of Texas at } \\
\text { Houston (UT) }\end{array}$ & $\begin{array}{l}\text { United } \\
\text { States }\end{array}$ & NCT00859014 \\
\hline $\mathrm{I} / \mathrm{II}$ & IV & $\begin{array}{l}\text { Mesenchymal bone marrow } \\
\text { cells }\end{array}$ & $>6 \mathrm{mo}$ & Safety & Functional outcome & $\begin{array}{l}\text { United States: } \\
\text { California, San Diego }\end{array}$ & $\begin{array}{l}\text { United } \\
\text { States }\end{array}$ & NCT01297413 \\
\hline Ila & IV & $\begin{array}{l}\text { Human placenta-derived, } \\
\text { PDA001 }\end{array}$ & $\begin{array}{l}\text { Acute to } \\
\text { subacute }\end{array}$ & Safety & Functional outcome & $\begin{array}{l}\text { Chattanooga Center } \\
\text { for Neurological } \\
\text { Research }\end{array}$ & $\begin{array}{l}\text { United } \\
\text { States }\end{array}$ & NCT01310114 \\
\hline I & IV, IA & $\begin{array}{l}\text { Autologous bone marrow } \\
\text { mononuclear }\end{array}$ & $\begin{array}{l}>3 \mathrm{~h} \text { and } \\
<90 \mathrm{~d}\end{array}$ & Safety, feasibility & Functional outcome & $\begin{array}{l}\text { Federal University of } \\
\text { Rio de Janeiro }\end{array}$ & Brazil & NCT00473057 \\
\hline $1 / I I$ & $\mathrm{IA}$ & $\begin{array}{l}\text { Autologous bone marrow CD } \\
34+\text { stem }\end{array}$ & Days 5- 9 & Safety & Functional outcome & $\begin{array}{l}\text { Hospital Universitario } \\
\text { Central de Asturias }\end{array}$ & Spain & NCT00761982 \\
\hline II & IA & $\begin{array}{l}\text { ALD-401 from autologous } \\
\text { bone marrow }\end{array}$ & $13-19 d$ & Safety & Functional outcome & $\begin{array}{l}\text { University of Texas at } \\
\text { Houston, Duke } \\
\text { University, LA Brain \& } \\
\text { Spine Institute }\end{array}$ & $\begin{array}{l}\text { United } \\
\text { States }\end{array}$ & NCT01273337 \\
\hline
\end{tabular}

Abbreviations: IA = intra-arterial; IC = intracerebral; IT = intrathecal.

livery could produce similar results with lesser cell doses; however, the optimal dose for IV or IA therapy is unclear. The initial clinical studies have essentially focused on feasibility of autologous cell procurement and the maximum viable cell dose that could be safely obtained prior to delivery.

Intra-arterial cell delivery in cardiac and peripheral vascular disease. Numerous initial clinical studies investigating IA cell delivery in patients post-myocardial infarction have demonstrated a trend toward improved clinical outcomes as well as physiologic parameters (increased contractility and improved myocardial perfusion, with decreased infarct size and end-systolic volume). ${ }^{32}$ These studies primarily utilized autologous bone marrow-derived cells and did not report any significant adverse events. Along similar lines, patients with peripheral vascular disease treated in clinical studies with IA or combined IA and IM injections of autologous bone marrow cells have demonstrated favorable outcomes so far. ${ }^{33}$ These studies also reported no significant adverse events, with improved ankle-brachial index, decreased claudication, and improved walking distance.
Preliminary human experience with intra-arterial cell delivery in ischemic stroke. In the first reported case of IA cell delivery in ischemic stroke, the authors performed IA autologous BMMNC infusion in a patient with left middle cerebral artery distribution infarct, 3 days after symptom onset. ${ }^{34}$ Prior to infusion, transcranial Doppler demonstrated intracranial arterial patency. The authors also reported a decrease in hypoperfusion on SPECT as well as increased metabolism in the ischemic tissue, 7 days after IA cell delivery. They subsequently reported another patient who underwent IA autologous BMMNC delivery in the left middle cerebral artery 9 days after stroke onset. ${ }^{35}$ They also labeled $1 \%$ of these cells with Tc-99m by incubating with hexamethylpropylene amine oxime and subsequently performed SPECT scanning, 8 hours following the IA infusion. They reported good clinical recovery and also mentioned that this method of in vivo cell tracking could be safe in humans after IA delivery.

More recently, a pilot study reported safety in IA BMMNC delivery in the middle cerebral artery in patients with chronic stroke. ${ }^{36}$ They reported no 
symptomatic worsening or significant adverse effects. One patient developed asymptomatic spike-wave activity following infusion. Two patients developed seizures 6 months after infusion, which were deemed unrelated to the infusion and treated with antiepileptic drugs.

Optimal endovascular techniques for intra-arterial cell delivery in ischemic stroke. As demonstrated by preclinical studies, prespecified endovascular technical details are the key to safety of this route of cell delivery. In patients with myocardial infarction receiving intracoronary cell delivery, the interventionalists used an over-the-wire single balloon catheter that was inflated to occlude flow for a few minutes, during which the cells were infused in the coronaries distal to the occlusion through the lumen of the balloon catheter. This maneuver was performed to allow for adhesion and transendothelial migration of the infused cells. ${ }^{37}$ The balloon would then be deflated to allow anterograde coronary flow, and this procedure was repeated until all the cells were delivered. Similarly, a double-balloon occlusion technique with ports in between the 2 balloons has been used for IA delivery of a high concentration of chemotherapeutic agents. ${ }^{38}$ Although the single or double balloon techniques have shown promise, ${ }^{37,38}$ this might not necessarily be the case in the more fragile cerebral blood vessel. ${ }^{39}$ As demonstrated recently in a preclinical study, preserved anterograde flow in the parent artery during IA cell delivery might be a safer technique in the craniocerebral vasculature. ${ }^{22}$

It is critical to have pre-established flow rates that do not affect viability of specific stem cells, with use of different microcatheters, heparinized saline, and angiographic contrast agents. A study has demonstrated that infusion of 10 million cells $/ \mathrm{mL}$ through the Excelsior SL-10 microcatheter (Boston Scientific, Fremont, CA) at rates of up to $2 \mathrm{~mL} / \mathrm{min}$ under standard temperature conditions did not affect viability of BMMNCs. ${ }^{40}$ Cell viability was also unaffected with exposure to Omnipaque (Nycomed, Princeton, $\mathrm{NJ})$ and low-dose heparin $(2.5 \mathrm{U} / \mathrm{mL})$ for 1 hour. There was a noticeable reduction in viability of BMMNCs at a concentration of 10 million cells $/ \mathrm{mL}$ with infusion rates in excess of $2 \mathrm{~mL} / \mathrm{min}$ and exposure to high-dose heparin $(500 \mathrm{U} / \mathrm{mL})$ for 1 hour. Another study demonstrated that infusion of human umbilical cord blood cells through the Excelsior SL-10 microcatheter (Boston Scientific) at concentration of 10 million cells/mL led to a reduction in viability. ${ }^{41}$ There was no affect on viability of these cells at a concentration of 1 million cells $/ \mathrm{mL}$, regardless of flow rates.

DISCUSSION Cell-based therapy is a potential adjunct therapeutic modality to acute revascularization therapies (IV thrombolysis or mechanical thrombectomy) for improved neurologic recovery in stroke patients. Despite the challenges in clinical translation from basic science studies, initial pilot studies have demonstrated safety and feasibility with IV and IA cell delivery. The ongoing clinical trials using various delivery routes, choice of cells, timing of therapy, and doses of cells are likely to bridge the knowledge gaps that exist with this therapy for patients with ischemic stroke.

\section{AUTHOR CONTRIBUTIONS}

Dr. Misra: drafting/revising the manuscript, study concept or design, analysis or interpretation of data. Mr. Ritchie: drafting/revising the manuscript, analysis or interpretation, acquisition of data. Ms. Stone and Dr. Low: drafting/revising the manuscript, study concept or design. Dr. Janardhan: drafting/revising the manuscript, study concept or design, analysis or interpretation of data, study supervision.

\section{DISCLOSURE}

Dr. Misra reports no disclosures. Mr. Ritchie holds stock in Novartis AG. Ms. Stone reports no disclosures. Dr. Low holds patents for biomarkers for ovarian cancer and biomarkers for breast cancer; serves as a consultant for Saneron CCEL; receives research support from NIH and HRK Foundation; receives research support from the University of Minnesota, AOSpine, International Organization of Glutaric Aciduria, and Gateway Foundation; and holds stock or stock options or expense compensation for serving on a board of directors from Saneron CCEL. Dr. Janardhan reports no disclosures. Go to Neurology.org for full disclosures.

Received October 20, 2011. Accepted in final form January 25, 2012.

\section{REFERENCES}

1. Savitz SI, Chopp M, Deans R, Carmichael ST, Phinney D, Wechsler L. Stem Cell Therapy as an Emerging Paradigm for Stroke (STEPS) II. Stroke 2011;42:825-829.

2. Misra V, Yang B, Sharma S, Savitz SI. Cell-based therapy for stroke. In: Cox C, editor. Progenitor Cell Therapy for Neurological Injury. New York: Springer; 2011:143-162.

3. Li Y, Chopp M, Chen J, et al. Intrastriatal transplantation of bone marrow nonhematopoietic cells improves functional recovery after stroke in adult mice. J Cereb Blood Flow Metab 2000;20:1311-1319.

4. Kondziolka D, Steinberg GK, Wechsler L, et al. Neurotransplantation for patients with subcortical motor stroke: a phase 2 randomized trial. J Neurosurg 2005; 103: $38-45$.

5. Savitz SI, Dinsmore J, Wu J, Henderson GV, Stieg P, Caplan LR. Neurotransplantation of fetal porcine cells in patients with basal ganglia infarcts: a preliminary safety and feasibility study. Cerebrovasc Dis 2005;20:101-107.

6. Jiang Q, Zhang ZG, Ding GL, et al. Investigation of neural progenitor cell induced angiogenesis after embolic stroke in rat using MRI. Neuroimage 2005;28:698-707.

7. Modo M, Stroemer RP, Tang E, Patel S, Hodges H. Effects of implantation site of stem cell grafts on behavioral recovery from stroke damage. Stroke 2002;33:2270-2278.

8. Rabinovich SS, Seledtsov VI, Banul NV, et al. Cell therapy of brain stroke. Bull Exp Biol Med 2005;139:126-128.

9. Hauger O, Frost EE, van Heeswijk R, et al. MR evaluation of the glomerular homing of magnetically labeled mesenchymal stem cells in a rat model of nephropathy. Radiology 2006;238:200-210. 
10. Kraitchman DL, Tatsumi M, Gilson WD, et al. Dynamic imaging of allogeneic mesenchymal stem cells trafficking to myocardial infarction. Circulation 2005;112:14511461.

11. Bang OY, Lee JS, Lee PH, Lee G. Autologous mesenchymal stem cell transplantation in stroke patients. Ann Neurol 2005;57:874-882.

12. Lee JS, Hong JM, Moon GJ, Lee PH, Ahn YH, Bang OY; STARTING Collaborators. A long-term follow-up study of intravenous autologous mesenchymal stem cell transplantation in patients with ischemic stroke. Stem Cells 2010;28:1099-1106.

13. Honmou O, Houkin K, Matsunaga T, et al. Intravenous administration of auto serum-expanded autologous mesenchymal stem cells in stroke. Brain 2011;134:1790-1807.

14. Savitz SI, Misra V, Kasam M, et al. Intravenous autologous bone marrow mononuclear cells for ischemic stroke. Ann Neurol 2011;70:59-69.

15. Yang B, Strong R, Sharma S, et al. Therapeutic time window and dose response of autologous bone marrow mononuclear cells for ischemic stroke. J Neurosci Res 2011;89: 833-839.

16. Guzman R, De Los Angeles A, Cheshier S, et al. Intracarotid injection of fluorescence activated cell-sorted CD49d-positive neural stem cells improves targeted cell delivery and behavior after stroke in a mouse stroke model. Stroke 2008;39:1300-1306

17. Shen LH, Li Y, Chen J, et al. Intracarotid transplantation of bone marrow stromal cells increases axon-myelin remodeling after stroke. Neuroscience 2006;137:393-399.

18. Liu H, Honmou O, Harada K, et al. Neuroprotection by PIGF gene-modified human mesenchymal stem cells after cerebral ischaemia. Brain 2006;129:2734-2745.

19. Li L, Jiang Q, Ding G, et al. Effects of administration route on migration and distribution of neural progenitor cells transplanted into rats with focal cerebral ischemia, an MRI study. J Cereb Blood Flow Metab 2010;30:653-662.

20. Kamiya N, Ueda M, Igarashi $H$, et al. Intra-arterial transplantation of bone marrow mononuclear cells immediately after reperfusion decreases brain injury after focal ischemia in rats. Life Sci 2008;83:433-437.

21. Walczak P, Zhang J, Gilad AA, et al. Dual-modality monitoring of targeted intraarterial delivery of mesenchymal stem cells after transient ischemia. Stroke 2008;39:15691574.

22. Chua JY, Pendharkar AV, Wang N, et al. Intra-arterial injection of neural stem cells using a microneedle technique does not cause microembolic strokes. J Cereb Blood Flow Metab 2011;31:1263-1271.

23. Xiao J, Nan ZH, Motooka Y, Low WC. Transplantation of a novel cell line population of umbilical cord blood stem cells ameliorates neurological deficits associated with ischemic brain injury. Stem Cells Dev 2005;14:722-733.

24. Ramos-Cabrer P, Justicia C, Wiedermann D, Hoehn M. Stem cell mediation of functional recovery after stroke. PLoS One 2010;5:e12779.

25. Daadi MM, Davis AS, Arac A, et al. Human neural stem cell grafts modify microglial response and enhance axonal sprouting in neonatal hypoxic-ischemic brain injury. Stroke 2010;41:516-523.

26. Yang M, Wei X, Li J, Heine LA, Rosenwasser R, Lacovitti L. Changes in host blood factors and brain glia accompa- nying the functional recovery after systemic administration of bone marrow stem cells in ischemic stroke rats. Cell Transp 2010;9:1973-1984.

27. Walker PA, Letourneau PA, Bedi S, Shah SK, Jimenez F, Cox CS. Progenitor cells as remote "bioreactors": neuroprotection via modulation of the systemic inflammatory response. World J Stem Cells 2011;3:9-18.

28. Nan ZH, Grande A, Sanberg CD, Sanberg PR, Low WC. Infusion of human umbilical cord blood ameliorates neurologic deficits in rats with hemorrhagic brain injury. Ann NY Acad Sci 2005;1049:84-96.

29. Kranz A, Wagner DC, Kamprad M, et al. Transplantation of placenta-derived mesenchymal stromal cells upon experimental stroke in rats. Brain Res 2010;1315:128-136.

30. Vendrame M, Cassady J, Newcomb J, et al. Infusion of human umbilical cord blood cells in a rat model of stroke dose-dependently rescues behavioral deficits and reduces infarct volume. Stroke 2004;35:2390-2395.

31. Honma T, Honmou O, Iihoshi $\mathrm{S}$, et al. Intravenous infusion of immortalized human mesenchymal stem cells protects against injury in a cerebral ischemia model in adult rat. Exp Neurol 2006;199:56-66.

32. Dimmeler S, Zeiher AM. Cell therapy of acute myocardial infarction: open questions. Cardiology 2009;113:155160

33. Lawall H, Bramlage P, Amann B. Stem cell and progenitor cell therapy in peripheral artery disease: a critical appraisal. Thromb Haemost 2010;103:696-709.

34. Mendonça ML, Freitas GR, Silva SA, et al. Safety of intraarterial autologous bone marrow mononuclear cell transplantation for acute ischemic stroke. Arq Bras Cardiol 2006;86:52-55

35. Correa PL, Mesquita CT, Felix RM, et al. Assessment of intra-arterial injected autologous bone marrow mononuclear cell distribution by radioactive labeling in acute ischemic stroke. Clin Nucl Med 2007;32:839-841.

36. Battistella V, de Freitas GR, da Fonseca LM, et al. Safety of autologous bone marrow mononuclear cell transplantation in patients with nonacute ischemic stroke. Regen Med 2011;6:45-52.

37. Assmus B, Schächinger V, Teupe C, et al. Transplantation Of Progenitor Cells And Regeneration Enhancement in Acute Myocardial Infarction (TOPCARE-AMI). Circulation 2002;106:3009-3017.

38. Terai Y, Kanemura M, Sasaki H, et al. Long-term follow-up of neoadjuvant intraarterial chemotherapy using an original four-lumen double-balloon (4L-DB) catheter for locally advanced uterine cervical cancer. Int J Clin Oncol 2009; 14:56-62

39. Janardhan V, Biondi A, Riina H, Sanelli PC, Stieg PE, Gobin YP. Vasospasm in aneurysmal subarachnoid hemorrhage: diagnosis, prevention, and management. Neuroimaging Clin North Am 2006;16:483-496.

40. El Khoury R, Misra V, Sharma S, et al. The effect of transcatheter injections on cell viability and cytokine release of mononuclear cells. AJNR Am J Neuroradiol 2010;31: $1488-1492$.

41. Janardhan V, Qureshi AI, Low WC. Intravascular delivery systems for stem cell transplantation for neurological disorders. In: Low WC, Verfaillie CM, eds. Stem Cells and Regenerative Medicine. Singapore: World Scientific Publishing; 2008:355-396. 


\section{Neurology}

\section{Stem cell therapy in ischemic stroke: Role of IV and intra-arterial therapy \\ Vivek Misra, Michael M. Ritchie, Laura L. Stone, et al. \\ Neurology 2012;79;S207-S212 \\ DOI 10.1212/WNL.0b013e31826959d2}

This information is current as of September 24, 2012

Updated Information \&

Services

References

Permissions \& Licensing

Reprints including high resolution figures, can be found at:

http://n.neurology.org/content/79/13_Supplement_1/S207.full

This article cites 39 articles, 9 of which you can access for free at: http://n.neurology.org/content/79/13_Supplement_1/S207.full\#ref-list1

Information about reproducing this article in parts (figures,tables) or in its entirety can be found online at:

http://www.neurology.org/about/about_the_journal\#permissions

Information about ordering reprints can be found online:

http://n.neurology.org/subscribers/advertise

Neurology ${ }^{\circledR}$ is the official journal of the American Academy of Neurology. Published continuously since 1951, it is now a weekly with 48 issues per year. Copyright Copyright (? 2012 by AAN Enterprises, Inc.. All rights reserved. Print ISSN: 0028-3878. Online ISSN: 1526-632X.

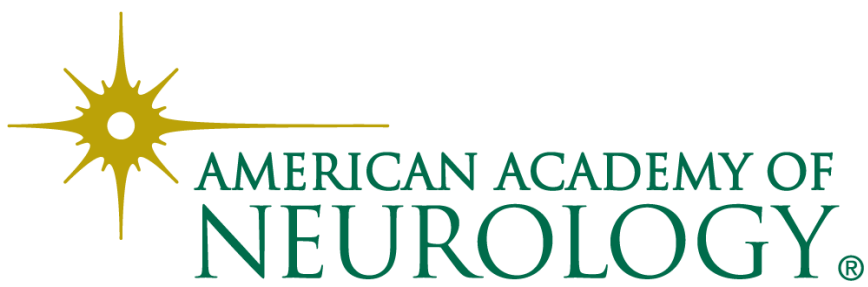

